\title{
The Influence of Workload, Job Satisfaction and Work Motivation on Nurse Performance in Hospital Inpatient Installation
}

\author{
Dian Rosyidawati ${ }^{1}$, Noer Bahry Noor ${ }^{1}$, Andi Zulkifli ${ }^{2}$ \\ dianrosyidawati@gmail.com
}

${ }^{1}$ Hospital Management Department, Faculty of Public Health, Hasanuddin University, Indonesia ${ }^{2}$ Epidemiology Department, Faculty of Public Health, Hasanuddin University, Indonesia

Received: November 2, 2020

Received in Revised: November 23, 2020

Accepted: November 30, 2020

\begin{abstract}
Work performance in quality and quantity achieved by an employee in carrying out his duties in accordance with the responsibilities assigned to him. This study aims to analyze the effect of workload, job satisfaction and work motivation on the performance of nurses in the inpatient installation of dr. Tadjuddin Chalid Hospital and Makassar City Hospital. This type of research is a quantitative study using an observational study with a cross sectional study design. The sample in this study were nurses in the inpatient installation of dr. Tadjuddin Chalid Hospital and Makassar City Hospital, totaling 170 respondents. The results showed that there was an effect of workload on the performance of nurses, there was an effect of job satisfaction on the performance of nurses, there was an effect of work motivation on the performance of nurses at dr. Tadjuddin Chalid and Makassar City Hospital. It is suggested to the hospital management that the need for improvement in nursing management, especially the division of duties and working hours of nurses to reduce the workload of nurses so as not to cause work stress that can impact on the performance of nurses, to further increase the work satisfaction of nurses by continuing to carry out fair rewards and punishments sytem, giving motivation, both material and nonmaterial, for nurses who have good performance to be able to maintain their performance while still carrying out their duties based on the applicable rules. For nurses who have poor performance, they can improve their performance by paying more attention to work targets to be achieved for the advancement and image of the organization as well as the quality of services provided to patients.
\end{abstract}

Keywords: Workload, Job Satisfaction, Work Motivation, Performance, Nurses

\section{Introduction}

Performance is the result of both quantitatively and qualitatively of the employees fulfilling their obligation according to their duties. The role of trust and professional staff is very effective in improving institutional performance. The quality of employees who are still far from adequate will certainly affect the resulting achievements. To achieve optimal performance requires an interaction and coordination designed to connect tasks, both individuals and groups in order to achieve organizational goals (Mangkunegara, 2012).

Finkler \& Kovner (2000) in Huber (2000), states that the workload of nurses is the work volume of nurses per unit divided by the number of nurses in the unit. Furthermore, Yoder \& Wise (2003) stated that the work volume is the time required to handle patients per day multiplied by 
the number of patients in a day. A head of the room can find out the activities of the executive nurse based on the workload given to the nurse. According to Ilyas (2000), nurses, workload analysis can be seen from aspects such as tasks that are carried out based on the main function and additional tasks performed, the number of patients who must be cared for, their work capacity according to the education they receive, working time. which is used to carry out their duties in accordance with working hours that take place every day, as well as complete facilities that can help nurses complete their work properly (Syaer, 2010). The results of the workload analysis of nurses can be used as a basis for knowing the proportion of time used for productive or unproductive activities, the workload pattern of nurses with working time and schedule and knowing the number of nurses in the hospital (Ilyas, 2004).

Motivation can be viewed as a change in energy in a person which is marked by the emergence of feelings, and is preceded by a response to a goal. Motivation is the basic impulse that moves a person or the desire to devote all his energy to a purpose. As stated by Mangkunegara (2009) motivation is a condition or energy that moves employees who are directed or aimed at achieving company organizational goals. The positive mental attitude of employees towards work situations is what strengthens their work motivation to achieve maximum performance. Therefore, to achieve the expected performance of the company requires motivation from employees. With motivation and performance appraisal, organizational goals can be achieved and personal goals can also be achieved. Giving motivation to someone is a link that starts with needs, creates desires, causes action, and produces decisions.

Based on the results of interviews with several nurses at Dr. Tadjuddin Chalid and the Makassar City Hospital stated that nurses lacked enthusiasm in dealing with their work and always felt tired quickly because there was too much work to be done. This is indicated by several nurses who always arrive late. Some nurses also stated that they were not satisfied with their work because they felt that what they were doing was not in accordance with what they got. The data on job satisfaction of nurses at Dr. Tadjuddin Chalid, namely for 2018 amounted to 64.4\%, and Makassar City Hospital in 2017 was 73.2\%. It was found that in 2018 the level of performance of nurses in the inpatient installation of RSUP DR. Tadjuddin Chalid Makassar, namely with an average of $87.8 \%$ and Makassar City Hospital with an average of $75.70 \%$ that have not met nursing care standards (100\%) with details of nursing care, namely dimensions of nursing assessment, nursing diagnoses, planning, action nursing, evaluations, and nursing records.

Therefore, the researcher hopes to conduct further analysis regarding the influence of job stress variables, job satisfaction and work motivation on nurses' performance so that the hospital is able to provide quality health services and can increase patient satisfaction.

\section{Methods}

This type of research is a quantitative study using an observational study with a Cross Sectional Study approach. This research was conducted at Dr. Tadjuddin Chalid and Makassar City Hospital. The population in this study were all nurses in the Inpatient Installation of Dr. Tadjuddin Chalid and Makassar City Hospital. The research sample amounted to 167 people. The instrument used in data collection is a questionnaire, regarding the independent variables in the form of workload, job satisfaction and work motivation, while the dependent variable is the nurse performance variable.

Univariate analysis was conducted to obtain an overview of the research problem by describing each variable used in the study and the characteristics of the respondent. Univariate analysis 
consisted of descriptive analysis of the characteristics of the respondents, descriptive analysis of the research variables and analysis of the crosstabulation between the characteristics of the respondents and the research variables. Bivariate analysis was carried out to see the relationship between two variables, namely between the independent variable and the dependent variable. The statistical test used was the Chi Square test.

\section{Results and Discussion}

Table 1. Frequency Distribution of General Characteristics of Respondents at Dr. Tadjuddin Chalid Hospital and Makassar City Hospital

\begin{tabular}{|c|c|c|c|c|}
\hline \multirow[t]{2}{*}{ Characteristics } & \multicolumn{2}{|c|}{$\begin{array}{c}\text { Makassar City } \\
\text { Hospital } \\
\end{array}$} & \multicolumn{2}{|c|}{$\begin{array}{c}\text { Dr.Tajuddin Chalid } \\
\text { Hospital }\end{array}$} \\
\hline & $\mathbf{N}$ & $\%$ & $\mathbf{N}$ & $\%$ \\
\hline \multicolumn{5}{|l|}{ Age } \\
\hline 20-35 years & 29 & 30.85 & 21 & 28.77 \\
\hline $35-45$ years & 42 & 44.68 & 33 & 45.21 \\
\hline$>45$ years & 23 & 24.47 & 19 & 26.03 \\
\hline Total & 94 & 100.00 & 73 & 100.00 \\
\hline \multicolumn{5}{|l|}{ Sex } \\
\hline Male & 24 & 25.53 & 24 & 32.88 \\
\hline Female & 70 & 74.47 & 49 & 67.12 \\
\hline Total & 94 & $\mathbf{1 0 0 . 0 0}$ & 73 & 100.00 \\
\hline \multicolumn{5}{|l|}{ Length of Work } \\
\hline $3-5$ years & 19 & 20.21 & 6 & 8.22 \\
\hline 6-8 years & 51 & 54.26 & 47 & 64.38 \\
\hline$>8$ years & 24 & 25.53 & 20 & 27.40 \\
\hline Total & 94 & 100.00 & 73 & 100.00 \\
\hline \multicolumn{5}{|l|}{ Education } \\
\hline S.Kep (Bachelor) & 54 & 57.45 & 42 & 57.53 \\
\hline Ners & 40 & 42.55 & 31 & 42.47 \\
\hline Total & 94 & 100.00 & 73 & 100.00 \\
\hline \multicolumn{5}{|l|}{ Employment status } \\
\hline Civil Servant & 33 & 35.11 & 20 & 27.40 \\
\hline Others & 61 & 64.89 & 53 & 72.60 \\
\hline Total & 94 & 100.00 & 73 & 100.00 \\
\hline
\end{tabular}

Source: Primary Data, 2020

Table 1 shows the frequency distribution based on the characteristics of the sample at the research location, most of the respondents at the Tajuddin Chalid Hospital and Makassar City Hospital are at the age level of 35-45 years with the highest percentage, namely at Tajuddin Chalid Hospital with 33 respondents (45.21\%). Judging from gender, most of the respondents were female, namely at Makassar City Hospital, as many as 70 respondents $(74.47 \%)$. Judging from the length of work, most of the respondents were 6-8 years of work, the most was Tajuddin Chalid Hospital with 47 respondents $(64.38 \%)$. In terms of education, most of the nursing undergraduate respondents were Tajuddin Chalid Hospital with 42 respondents (57.53\%). And 
seen from the employment status, most of the other respondents who mostly are Tajuddin Makassar Hospital with 53 respondents (72.60\%).

Table 2. Frequency Distribution of Respondents Based on Research Variables at Dr. Tadjuddin Chalid Hospital and Makassar City Hospital

\begin{tabular}{|l|c|c|c|c|}
\hline \multirow{2}{*}{ Variable } & \multicolumn{2}{c|}{$\begin{array}{c}\text { Makassar City } \\
\text { Hospital }\end{array}$} & \multicolumn{2}{c|}{$\begin{array}{c}\text { Dr.Tajuddin Chalid } \\
\text { Hospital }\end{array}$} \\
\cline { 2 - 5 } & N & \% & N & \% \\
\hline \multicolumn{5}{|c|}{ Work Load } \\
\hline Low & 42 & 44.68 & 36 & 49.32 \\
\hline High & 52 & 55.32 & 37 & 50.68 \\
\hline Total & $\mathbf{9 4}$ & $\mathbf{1 0 0 . 0 0}$ & $\mathbf{7 3}$ & $\mathbf{1 0 0 . 0 0}$ \\
\hline \multicolumn{5}{|c|}{ Job Satisfaction } \\
\hline Low & 78 & 82.98 & 60 & 82.19 \\
\hline High & 16 & 17.02 & 13 & 17.81 \\
\hline Total & $\mathbf{9 4}$ & $\mathbf{1 0 0 . 0 0}$ & $\mathbf{7 3}$ & $\mathbf{1 0 0 . 0 0}$ \\
\hline \multicolumn{5}{|c|}{ Job Motivation } \\
\hline Low & 67 & 71.28 & 57 & 78.08 \\
\hline High & 27 & 28.72 & 16 & 21.92 \\
\hline Total & $\mathbf{9 4}$ & $\mathbf{1 0 0 . 0 0}$ & $\mathbf{7 3}$ & $\mathbf{1 0 0 . 0 0}$ \\
\hline \multicolumn{5}{|c|}{ Performance } \\
\hline Low & 51 & 54.26 & 29 & 39.73 \\
\hline High & 43 & 45.74 & 44 & 60.27 \\
\hline Total & $\mathbf{9 4}$ & $\mathbf{1 0 0 . 0 0}$ & $\mathbf{7 3}$ & $\mathbf{1 0 0 . 0 0}$ \\
\hline
\end{tabular}

Source: Primary Data, 2020

Table 2. explains the percentage of respondents' assessment of the research variables. The results of most respondents stated that they were in the high workload category in Makassar City Hospital and Tajuddin Chalid Regional Hospital with $55.32 \%$ and $50.68 \%$, respectively, in the low job satisfaction category in Makassar City Hospital and Tajuddin Chalid Regional Hospital with 82.98 respectively. $\%$ and $82.19 \%$, in the category of low work motivation in Makassar City Hospital and Tajuddin Chalid Regional Hospital with $71.28 \%$ and $78.08 \%$ respectively, in the high performance category of nurses in Makassar City Hospital and Tajuddin Chalid Regional Hospital with $92.55 \%$ and respectively. $91.78 \%$.

Table 3. The effect of workload, job satisfaction and work motivation on the performance of nurses in the Inpatient Installation of Dr. Tadjuddin Chalid Hospital and Makassar City Hospital

\begin{tabular}{|c|c|c|c|c|c|c|c|}
\hline \multirow{3}{*}{ Work Load } & \multicolumn{4}{|c|}{ Nurse Performance } & \multirow{2}{*}{\multicolumn{2}{|c|}{ Amount }} & \multirow{3}{*}{$p$} \\
\hline & \multicolumn{2}{|c|}{ High } & \multicolumn{2}{|c|}{ Low } & & & \\
\hline & $\mathbf{n}$ & $\%$ & $\mathbf{n}$ & $\%$ & $\mathbf{n}$ & $\%$ & \\
\hline High & 55 & 70.51 & 23 & 29.49 & 78 & 100.00 & \multirow{3}{*}{0.001} \\
\hline Low & 25 & 28.09 & 64 & 71.91 & 89 & 100.00 & \\
\hline Total & 80 & 47.90 & 87 & 52.10 & 167 & 100.00 & \\
\hline Job Satisfaction & \multicolumn{4}{|c|}{ Nurse Performance } & \multicolumn{2}{|c|}{ Amount } & $p$ \\
\hline
\end{tabular}




\begin{tabular}{|c|c|c|c|c|c|c|c|}
\hline & \multicolumn{2}{|c|}{ High } & \multicolumn{2}{|c|}{ Low } & \multirow[b]{2}{*}{$\mathbf{n}$} & \multirow[b]{2}{*}{$\%$} & \\
\hline & $\mathbf{n}$ & $\%$ & $\mathbf{n}$ & $\%$ & & & \\
\hline High & 80 & 57.97 & 58 & 42.03 & 138 & 100.00 & \multirow{3}{*}{0.001} \\
\hline Low & 0 & 0.00 & 29 & 100.00 & 29 & 100.00 & \\
\hline Total & 80 & 47.90 & 87 & 52.10 & 167 & 100.00 & \\
\hline \multirow{3}{*}{$\begin{array}{c}\text { Work } \\
\text { Motivation }\end{array}$} & \multicolumn{4}{|c|}{ Nurse Performance } & \multirow{2}{*}{\multicolumn{2}{|c|}{ Amount }} & \multirow{3}{*}{$p$} \\
\hline & \multicolumn{2}{|c|}{ High } & \multicolumn{2}{|c|}{ Low } & & & \\
\hline & $\mathbf{n}$ & $\%$ & $\mathbf{n}$ & $\%$ & $\mathbf{n}$ & $\%$ & \\
\hline High & 76 & 61.29 & 48 & 38.71 & 124 & 100.00 & \multirow{3}{*}{0.001} \\
\hline Low & 4 & 9.30 & 39 & 90.70 & 43 & 100.00 & \\
\hline Total & 80 & 47.90 & 87 & 52.10 & 167 & 100.00 & \\
\hline
\end{tabular}

Source: Primary Data, 2020

Table 3. shows the relationship between the independent variable and the dependent variable. Based on the results of the analysis, it can be seen that the influence of workload variables, job satisfaction and work motivation on the performance of nurses in the Inpatient Installation of Dr. Tadjuddin Chalid and Makassar City Hospital. The results of the bivariate analysis with the chi square test showed that there was an influence of the workload variable on the performance of the nurses at Dr. Tadjuddin Chalid and Makassar City Hospital with a $p$ value $=0.001<0.05$, there is an effect of work baggage variables on the performance of nurses at Dr. Tadjuddin Chalid and Makassar City Hospital with p value $=0.001<0.05$, there is an effect of work motivation variables on the performance of nurses at Dr. Tadjuddin Chalid and Makassar City Hospital with $\mathrm{p}$ value $=0.001<0.05$.

The results of the study were based on the workload variable in Dr. Tadjuddin Chalid obtained was $50.68 \%$ and in Makassar City Hospital it was 55.32\%. This shows the high workload caused by other additional tasks and is often carried out but activities that are not its function, such as handling non-nursing (such as taking care of patient administration, room inventory, managing medical records, completing papers, preparing linens, even collecting prescriptions at pharmacies for patients).

The workload must be in accordance with the ability of the duty officer (nurse) so that performance can be maintained properly. Manpower management that is not well planned can lead to subjective complaints, heavier, ineffective and inefficient workloads that allow work dissatisfaction which ultimately results in decreased performance and productivity as well as decreased service quality. To further improve the effectiveness and management of personnel, care leaders must balance the number of personnel and the workload of nurses. A high workload is burdensome psychologically so that it has the potential to cause low nurse performance. Research conducted by Indriani (2018) states that the regression coefficient value is -0.164 , a positive value indicates that workload has a negative effect on the performance of inpatient care. The lower the workload of nurses who carry out inpatient care in working such as physical, psychological and working time burdens, it can improve the performance of the implementation of inpatient care. Physical burden on nurses can be indicated by excessive fatigue at work.

Psychological burden can be indicated by a sense of working under pressure, superiors cannot motivate the work of the nurses and feel bored with the work atmosphere. Time load can be indicated by too heavy a given working hour and frequent shifts back and forth so that it interferes with working time. The sig value obtained is 0.005 smaller than the error rate of the 
study (0.05), so the workload has a significant effect on the performance of inpatient care. If the inpatient care nurse can control the burden physically, psychologically and time, the nurse will be easy to carry out patient assessments, will be easy to make a diagnosis, and can properly plan, implement and evaluate each of her duties and functions as a nurse. If this continues, it will affect the performance of the implementation of inpatient care.

The results of the study were based on the variable job satisfaction at Dr. Tadjuddin Chalid obtained was $82.98 \%$ and in Makassar City Hospital was $82.98 \%$. This shows the low job satisfaction of nurses because nurses feel that the work done is not in accordance with the job description, does not have the opportunity to learn to develop abilities and the salary given is not in accordance with the load or responsibilities that are carried.

A strong organization has the ability to create and maintain employee job satisfaction so that it will stimulate employees to work well according to predetermined standards and have a high commitment to the company. Every individual who works hopes to get satisfaction from his place of work. Basically, job satisfaction is an individual thing because each individual will have a different level of satisfaction according to the values that apply in each individual.

The job satisfaction referred to in this study is to find out how the perceptions of nurses who work at the General Hospital (RSUP Dr. Tadjuddin Chalid and RSUD Kota Makassar) on feedback from their own work, salaries and rewards received, promotion opportunities, supervision at work, colleagues work or cooperative team members, and the effects of the work environment. Hasibuan (2002) suggests that the power that motivates a person to work actively in doing his job depends on the reciprocal relationship between what he wants and needs from the results of the work. How much does he believe the company will provide satisfaction for his wishes in return for the effort he does. If the expected confidence is big enough to get his satisfaction, he will work hard and have high commitment to the company or organization and vice versa.

According to Colquiit et al (2011) job satisfaction is a predictor of performance because job satisfaction has a moderate correlation with performance. Satisfied workers do a better job at fulfilling their obligations according to the job description. Job satisfaction has a moderate positive effect on performance. People who have a higher level of job satisfaction tend to have a higher level of task performance, a higher level of citizenship behavior and a lower level of counter-productive behavior.

The results of research conducted by Luthfan (2011) show that job satisfaction (aspects of salary, working conditions, coworkers, supervisors, and work itself) has a positive and significant effect on nurse performance. Furthermore, research conducted by Nurhayani (2012) shows that there is a relationship between job satisfaction (work environment conditions, incentives, opportunities for self-development, supervisory relationships, and coworker relationships) with the performance of nurses in the Inpatient Room of RSU Daya Makassar City.

Research conducted by As'ad (2013) shows that there is a relationship between job satisfaction in the aspects of work, salary, development opportunities, coworkers and supervision with nurse performance, and there is no relationship between job satisfaction aspects of work conditions and leadership with nurse performance. The same research was also conducted by Argapati (2013) showing the level of job satisfaction of nurses that out of 130 respondents, 79 respondents $(60.8 \%)$ were satisfied and 51 respondents $(39.2 \%)$ were dissatisfied. This level of satisfaction is based on the aspects of interest, job tranquility, skills, social interaction between nurses and 
superiors, social interactions between nurses, work and rest time arrangements, work equipment, room conditions, salary, social security, benefits, and promotions.

The results of the study were based on work motivation variables in Dr. Tadjuddin Chalid obtained was $71.28 \%$ and in Makassar City Hospital was $82.19 \%$. This shows the low work motivation because nurses feel that they have lost their morale and feel that the performance allowance provided is not appropriate.

Motivation is needed because with motivation, employees will be more enthusiastic and responsible for their work so that performance can be better. Motivation is a human psychological characteristic that contributes to a person's level of commitment. This includes the factors that cause, transmit and sustain human behavior in a particular direction of determination. Motivation is anything that encourages someone to do something. Motivation is a feeling or thought that encourages someone to do work or exercise power, especially in behavior (Nursalam, 2014).

The results of this study are in accordance with research conducted by Hasniah (2013) regarding the relationship between work motivation and performance of nurses in the Salewangan Maros Hospital inpatient unit, where the results showed that as many as $78.9 \%$ of nurses had poor work motivation. Research Sulastri (2002) research on the effect of work motivation on employee work performance, obtained good motivation as many as 31 people (72.0\%) while less good motivation is 12 people $(28.0 \%)$, because in research in the ward Inpatients at Alimuddin Umar Regional Hospital, West Lampung Regency, found that the work motivation of the nurse administrators was not good enough.

The results of this study are in line with Vroom's (2001) theory in Nursalam (2014) on cognitive theory of motivation explaining why a person will not do something that he believes he cannot do, even though the results of the job he really wants. According to Vroom, the level of a person's motivation is determined by three components, namely the expectation (hope) of success in a task, instrumental, namely an assessment of what will happen if successful in performing a task (the success of the task to get a certain outcome), valence, namely response towards outcomes such as feeling positive, neutral, or negative. High motivation if the effort produces something that exceeds expectations Low motivation if the effort produces less than expected.

\section{Conclusion}

There is an effect of workload on the performance of nurses, there is an effect of job satisfaction on the performance of nurses, there is an effect of work motivation on the performance of nurses at dr. Tadjuddin Chalid and Makassar City Hospital. It is suggested to the hospital management that the need for improvement in nursing management, especially the division of duties and working hours of nurses to reduce the workload of nurses so as not to cause work stress that can impact on the performance of nurses, to further increase the work satisfaction of nurses by continuing to carry out fair rewards and punishments sytem, giving motivation, both material and non-material, for nurses who have good performance to be able to maintain their performance while still carrying out their duties based on the applicable rules. For nurses who have poor performance, they can improve their performance by paying more attention to work targets to be achieved for the advancement and image of the organization as well as the quality of services provided to patients. 


\section{References}

Argapati, A.K. (2013). Gambaran Kepuasan Kerja Perawat Rawat Inap Rumah Sakit Stella Maris Makassar. Makassar: UNHAS.

As’ad, Moh. (2013). Psikologi Industri, Seri Ilmu Sumber Daya Manusia, Liberty, Jakarta.

Colquitt JA., Lepine JA., Michael JW. (2011). Organizational Behavior Improving Performance and Commitment in the workplace (2nd ed). New York : McGrawHill

Finkler, S., \& Kovner, C. (2000). Financial Management for Nurse Managers and Executives. USA: W.B Saunders Company

Huber, D.L. (2010). Leadership and nursing care management. Ed 4. Missouri: Saunders Elsevier.

Ilyas, Y. (2002). Kinerja, teori, penilaian, dan penelitian. Jakarta. Pusat Kajian Ekonomi Kesehatan FKM Universitas Indonesia.

Ilyas, Y. (2004). Perencanaan SDM Rumah Sakit : Teori, Metoda, dan Formula. Depok. FKMUI.

Mangkunegara, Anwar. P. (2009). Manajemen Sumber Daya Manusia Perusahaan, Bandung : PT Remaja Rosdakarya.

Nursalam. (2006). Manajemen keperawatan: Aplikasi dalam praktik keperawatan profesional. Jakarta: Salemba Medika.

Nursalam. (2002). Manajemen Keperawatan: Aplikasi dalam Praktek Keperawatan Profesional. Jakarta: Salemba Medika.

Nursalam. (2007). Managemen Keperawatan: Aplikasi dalam Praktik Keperawatan Profesional. Jakarta : Salemba Medika

Sageer., Sameena, Rafat., Puja, Agarwal. (2012). Identification of Variables Affecting Employee Satisfaction and Their Impact on the Organization. Journal of Business and Management, 1:32-39.

Vroom Victor H. (2001). Work and Motivation, (New York : John Wiley \& Son, Inc., 1964.

Yoder-Wise, Patricia. (1999). Leading Managing in Nursing. Third edition. Missouri. Mosby. 